\title{
Effect of storage on composition, physico-chemical, rheology, sensory and microbiological quality of Indian cookie Rava Burfi
}

\author{
Aparna A. Shrivas ${ }^{1}$, Suneeta V. Pinto ${ }^{1 *}$, Sunil M. Patel ${ }^{2}$ and Smitha Balakrishnan ${ }^{3}$ \\ ${ }^{1}$ Department of Dairy Technology, SMC College of Dairy Science, Anand Agricultural University, Anand-388110 \\ (Gujarat), INDIA \\ ${ }^{2}$ Department of Dairy Engineering, SMC College of Dairy Science, Anand Agricultural University, Anand-388110 \\ (Gujarat), INDIA \\ ${ }^{3}$ Department of Dairy Chemistry, SMC College of Dairy Science, Anand Agricultural University, Anand-388110 \\ (Gujarat), INDIA \\ *Corresponding author. E-mail: suneetavpinto@aau.in \\ Received: June 15, 2017; Revised received: August 10, 2017; Accepted: January 15, 2018
}

\begin{abstract}
In the present study, changes in compositional, physico-chemical, rheological, sensory and microbial properties (SPC, coliform count and yeast and mould count) of rava burfi packed in composite polyethylene terephthalate (PET)/low density polyethylene (LDPE) film was monitored during storage at room temperature $\left(30 \pm 2{ }^{\circ} \mathrm{C}\right)$ and refrigerated temperature $\left(7 \pm 2{ }^{\circ} \mathrm{C}\right)$ on every $3^{\text {rd }}$ for room temperature and on every $7^{\text {th }}$ day for refrigerated temperature of storage till the products became unacceptable. All the changes related to composition, acidity, water activity, Free Fatty Acid (FFA), soluble nitrogen, 5-Hydroxy Methyl Furfural (HMF) and Thiobarbituric Acid (TBA), rheological, sensory and microbiological properties of rava burfi were found to be significantly $(P<0.05)$ affected by storage period (i.e. 9 days at room temperature $\left(30 \pm 2{ }^{\circ} \mathrm{C}\right)$ and 35 days at refrigerated $\left(7 \pm 2^{\circ} \mathrm{C}\right)$ temperature). During storage period there was a decrease in moisture content $(2.5$ to $3.0 \%)$ and water activity and an increase in fat, protein, lactose, ash, added sugar, acidity, FFA, soluble nitrogen, TBA and HMF both at ambient $\left(30 \pm 2{ }^{\circ} \mathrm{C}\right)$ as well as at refrigerated $\left(7 \pm 2^{\circ} \mathrm{C}\right)$ temperature. Changes in rheological attributes at both ambient and refrigerated temperatures of storage indicated that there was an increase in hardness, gumminess, chewiness and adhesiveness whereas there was decrease in cohesiveness and springiness values. The sensory scores in terms of flavour, body and texture, colour and appearance and overall acceptability were found to be significantly $(P<0.05)$ decrease with progressive increase in storage period. The shelf life of rava burfi was found to be 9 days at room temperature $\left(30 \pm 2{ }^{\circ} \mathrm{C}\right)$ and 35 days at refrigerated $\left(7 \pm 2^{\circ} \mathrm{C}\right)$ temperature.
\end{abstract}

Keywords: Burfi, Cereal, Khoa, Rava, Semolina

\section{INTRODUCTION}

Burfi is one of the most popular khoa based sweet in India. Once confined to household production, burfi is gaining an international market in recent years owing to its delicious taste, flavour and texture. The most popular varieties of burfi are fruit, nut, chocolate, saffron and rava burfi. These ingredients can be used singly or in combination (Aneja et al., 2002).It is prepared from a mixture of pindi khoa and sugar, heating to near homogenous consistency. Beating and whipping operations prior to cooling are sometimes practiced to obtain a product with smooth texture and closely knit body. It is white to light cream in colour with firm body and smooth texture with very fine grains (Patil and Pal, 2005). Khoa has a unique adaptability in terms of flavour, body and texture to blend with a wide range of ingredients resulting in the development of a wide range of varieties of burfi. Several varieties of burfi are available in the market such as plain or mawa/khoa burfi, fruit and nut, cashew burfi, chocolate, saffron and rava burfi (Sachdeva and Rajorhia, 1982; Sarkar et al., 2002). Cereals in milk are blended to compensate for deficiency of lysine in proteins. Cereals in combination with milk will make up the deficiency of protein quality of cereals. Cereals also constitute a source of calcium, iron and B vitamins (Millward et al., 2002). Moreover, at present the cost of semolina is about $1 / 12^{\text {th }}$ that of milk solids.

Rava burfi is a heat desiccated sweetmeat prepared from a mixture of milk solids, rava (semolina) and sugar and sometimes garnished with nuts. At present there is no legal definition for burfi in India. However, BIS (IS:5550-1970) has mentioned requirements for different varieties of burfi. BIS has suggested standards for three types of burfi i.e. (a) milk or mawa burfi, (b) fruit, nut, chocolate or cocoa burfi and (c) rava burfi containing khoa, sugar and rava together with 
flavouring and colouring material. Khan et al. (2008) studied the changes in quality of groundnut burfi packed in polypropylene (PP, 75 $\mu$ ) and metallized polyester $(12 \mu)$ low density/linear low density (MP, $75 \mu$ ) during storage in order to assess the shelf life. The samples without sorbic acid spoiled within 30 days of storage due to mold growth and fermented odour. Groundnut burfi containing sorbic acid ( 0.3 per cent) did not support any microbial growth during storage of up to 8 months. Groundnut burfi remained stable and acceptable up to 6 months and 8 months under ambient temperatures $\left(15-34{ }^{\circ} \mathrm{C}\right)$ in $\mathrm{PP}$ and MP pouches, respectively. Sachdeva and Rajorhia (1982) studied the chemical and microbiological changes in plain burfi during storage at room and refrigerated temperatures using two packaging materials viz., parchment paper and tin containers. The shelf life of burfi when stored in parchment paper was found 10 days at $30^{\circ} \mathrm{C}$ and 50 days at $5.0 \pm 1^{\circ} \mathrm{C}$ whereas burfi packed in tin containers had a shelf life of more than 105 days at $5.0 \pm 1^{\circ} \mathrm{C}$.

Burfi with high moisture develops a hard structure and crystallization of sugar during long storage (Anon, 1979; 2012). The use of potassium sorbate @ 0.1 per cent followed by vacuum packaging preserved burfi samples in good conditions for more than 60 days (Patil and Pal, 2005). Vijayalakshmi et al. (2005) reported that a free $\mathrm{O}_{2}$ absorber coupled with high - barrier materials like metalized films/foil laminates gave more than 45 days shelf life to burfi at $27^{\circ} \mathrm{C}$.

Shelf-life of burfi is most important from manufacturing and consumer point of view. To make rava burfi as commercially viable product, it should have sufficient shelf-life. The growth of the microorganisms brings about various changes in the product and spoils the taste of the product during storage. Hence the study was planned to evaluate the shelf life of rava burfi when stored at refrigeration and room temperatures.

\section{MATERIALS AND METHODS}

Standardized milk $(4.6 \pm 0.2 \%$ fat/ $8.6 \pm 0.05 \%$ SNF $)$ was used as the base material for preparation of khoa. Rava was procured from local market and the composition of rava. The product was analyzed for its proximate compositon and it was found to be $68.93 \%$ carbohydrate, $0.2 \%$ fat, $12.5 \%$ protein, $0.8 \%$ ash, $3.9 \%$ crude fibre and $10.4 \%$ moisture. Ghee of Amul Brand, Amul Dairy, Anand in Gujarat was used for roasting of rava. Cane sugar used was of commercial grade (M grade) which was obtained from the local market of Anand. Liquid glucose (Gujarat Ambuja Ltd., Ahmedabad) having a Dextrose Equivalent (DE) of 38-44 was procured used with $85.00 \pm 1.00 \% \mathrm{TS}, 4.8-5.2 \mathrm{pH}, 1$ (ml of $\mathrm{NaOH} 0.1 \mathrm{M})$ max. Free acidity, 38-44 DE and $0.25 \%$ Ash max.

Analysis: Fat extraction of khoa and burfi were determined as per the procedure described in IS:2311
(1963). In this method, the sample is treated with ammonia to dissolve the proteins and ethyl alcohol to help precipitate the proteins. Thereafter, the fat is extracted with diethyl ether and petroleum ether. The mixed ethers are then evaporated and the residue weighed. Total nitrogen/protein of khoa and burfi was determined by Semi-Microkjeldahl method (IS:1479-PartII, 1961). Ash content of all the samples was determined by procedure described in IS:1547 (1985). Lactose was derived by difference of sum total of the major constituents like moisture, protein, fat and ash from 100. Reducing and non-reducing sugars of burfi was determined by the volumetric method specified for icecream in IS:2802 (1964). The starch content of burfi was determined by the method given in ISI Handbook (1989). The crude fiber content of burfi was determined by the method given in IS:1155 (1968). The acidity of burfi was determined by method described in BIS (IS:1166-1968) for condensed milk. The $\mathrm{pH}$ of burfi was measured using Systronic digital $\mathrm{pH}$ meter, Model 335. The water activity of burfi samples, tempered at $25^{\circ} \mathrm{C}$ temperature, was measured using Rotronic Hygroskop Model: Hygrolab-3 (M/s. Rotronicag, Switzerland) connected to a sensing element (AW -DIO) with a measuring range of $0-100 \%$ relative humidity (RH). The method prescribed by Deeth et al. (1975) was used to estimate the FFA content of burfi. The quantitative method presented by Keeney and Bassette (1959) for quantifying HMF by spectrophotometric measurement of the 2-thio barbituric acid (TBA) reaction product was used to assess the extent of browning in burfi samples with slight modification. The extent of oxidation of fat in burfi was measured in terms of TBA value. The extraction method of Strange et al. (1977) was followed with slight modification. TBA value was expressed as absorbance (OD) at 532 $\mathrm{nm}$. The soluble nitrogen contents of burfi sample were determined by the procedure outlined by Kosikowaski (1982).

The moisture of semolina was determined by procedure described in IS: 1010 (1968). The protein content of semolina was determined by Kjeldahl method as described by AOAC (1970). The starch content of semolina was determined by the method given in ISI Handbook (1989) using 2 g sample. Total ash of semolina was determined by standard procedure given in IS:1010 (1968). The crude fiber of semolina was determined by the method given in ISI Handbook (1989) using 2 g sample.

Sensory evaluation: For the organoleptic evaluation of burfi, judges who were familiar with desirable attributes of burfi were selected. The selection criterion was that subjects had to be regular consumers of typical dairy sweets as well as their similar behavior between sensory evaluation sessions. The samples were subjected to sensory evaluation as described in using a 9 point hedonic scale score card as suggested by Stone 
and Sidel (2004). The judges were also requested to note down their observations/comments for each attribute specified in the score card. The burfi samples were tempered at room temperature for 1-2 hour before judging. Sensory evaluation of the samples was conducted in isolated booths illuminated with incandescent light and maintained at $28 \pm 2{ }^{\circ} \mathrm{C}$. Samples were served on SS dishes covered with polystyrene dish. The samples were labelled with three-digit codes. The order of presentation of the samples was randomized across subjects. The sensory panel $(n=7)$ was composed of staff members and post graduate students working in the institution.

Texture profile analysis: Four samples of each experimental burfi were subjected to uniaxial compression to $80 \%$ of the initial sample height, using a Food Texture Analyzer of Lloyd Instruments LRX Plus material testing machine, England; fitted with 0-500 kg load cell. The force-distance curve was obtained for a two-bite deformation cycle employing a Cross Head speed of $50 \mathrm{~mm} / \mathrm{min}$, Trigger 10 gf and $80 \%$ Compression of the samples to determine various textural attributes of burfi held for 1 hour at $23 \pm 1{ }^{\circ} \mathrm{C}$ and $55 \%$ relative humidity $(\mathrm{RH})$.

Microbiological analysis: All the burfi samples were analyzed for the Standard Plate Count (SPC), Coliform count and Yeast and Mold count (YMC) by the methods as described in IS:5550 (2005).

Statistical analysis: The mean value generated from the analysis of samples of rava burfi, obtained in three replications were subjected to statistical analysis using completely randomized design (CRD) as per Steel and Torrie (1980).

Preparation of khoa for manufacture of rava burfi: Standardized milk (4\% fat) was forewarmed (85 $\mathrm{C} / 10 \mathrm{~min}$ ) and pre concentrated to $50 \%$ total solids in vacuum pan operated at $62 \mathrm{~cm}$ of $\mathrm{Hg}$. Khoa was prepared from pre-concentrated milk by heat desiccation in a steam jacketed stainless steel open pan operated at $0.5 \mathrm{~kg} / \mathrm{cm}^{2}$ steam pressure with continuous manual stirring and scrapping. The process of heating stirring was continued till the product acquired desired consistency. The finished product was subsequently transferred to enamel trays, worked to pat form and packaged in sanitized polyethylene pouches. The samples were stored at room temperature $\left(25\right.$ to $\left.30^{\circ} \mathrm{C}\right)$ for 18 20 hours.

Processing of rava for manufacture of rava burfi:
Rava (small particle grade) (250 g) was spread uniformly on SS dish (1 cm thickness), covered with a SS lid, and autoclaved at $121{ }^{\circ} \mathrm{C}$ for $15 \mathrm{~min}$. The contents were transferred to a thick bottomed SS karahi. The steamed rava was then roasted with $100 \mathrm{~g}$ ghee for 10 min at $140{ }^{\circ} \mathrm{C}$ till light brown colour was obtained.

Preparation of sugar syrup for manufacture of rava burfi: Weigh the desired amount of sucrose (190 g) and liquid glucose $(36 \mathrm{~g})$. Add $100 \mathrm{ml}$ potable water. Boil the contents till the concentrate on reached 80 brix.

Preparation of rava burfi: Rava burfi was prepared according to the method standardized by Shrivas et al. (2015). Khoa (400 g) is blended with the processed rava and sugar syrup (boiling condition) and whipped well for $5 \mathrm{~min}$. The contents are then poured on a greased tray and allowed to set overnight at room temperature. The contents are then cut into square pieces $3 \times 3 \mathrm{~cm}$. The rava burfi was packed in Composite polyethylene terephthalate (PET)/low density polyethylene (LDPE) film (50 $\mu$ thickness) pouches and placed in PE box. The pouches were dipped in 0.5 per cent $\mathrm{H}_{2} \mathrm{O}_{2}$ solution and dried in an oven maintained at $60-65{ }^{\circ} \mathrm{C}$ for $30 \mathrm{~min}$. Two hundred $\mathrm{g}$ of product was packed in each package.

The compositional, physico-chemical, rheological, sensory and microbial properties (SPC, coliform count and yeast and mould count) of fresh and stored samples of rava burfi were monitored at predetermined time interval, after every $3^{\text {rd }}$ day for room temperature $\left(30 \pm 2{ }^{\circ} \mathrm{C}\right)$ and every $7^{\text {th }}$ day for refrigerated temperature $\left(7 \pm 2{ }^{\circ} \mathrm{C}\right)$. Stored rava burfi was rejected on sensory basis as well as visible yeast and mould growth. This experiment was carried out in three replications. The results of replications on storage related changes in rava burfi are presented and discussed in this section.

\section{RESULTS AND DISCUSSION}

Effect of storage on composition of rava burfi: The storage changes taking place in the composition of rava burfi during storage at room and refrigerated temperature have been presented in Table 1and Table 2 respectively.

The values presented in Table 1 revealed that moisture content of rava burfi significantly $(\mathrm{P}<0.05)$ decreased from an initial moisture content of $19.29 \%$ to $17.53 \%$ during the storage period up to 9 days and thereafter

Table 1. Effect of storage period on composition of rava burfi at room temperature $\left(30 \pm 2{ }^{\circ} \mathrm{C}\right)$.

\begin{tabular}{llllll}
\hline \multirow{2}{*}{$\begin{array}{l}\text { Attribute } \\
(\%)\end{array}$} & \multicolumn{6}{l}{ Mean values of composition on storage for different periods in days } & \multirow{2}{*}{ CD (0.05) } \\
\cline { 2 - 5 } & $\mathbf{0}$ & $\mathbf{3}$ & $\mathbf{6}$ & $\mathbf{9}$ & 0.40 \\
Moisture & $19.29 \pm 0.41$ & $18.75 \pm 0.26$ & $18.16 \pm 0.24$ & $17.53 \pm 0.24$ & 0.05 \\
Fat & $18.40 \pm 0.01$ & $18.52 \pm 0.029$ & $18.65 \pm 0.029$ & $18.76 \pm 0.038$ & 0.06 \\
Total protein & $9.47 \pm 0.01$ & $9.56 \pm 0.05$ & $9.64 \pm 0.03$ & $9.68 \pm 0.03$ & 0.003 \\
Ash & $1.57 \pm 0.01$ & $1.58 \pm 0.001$ & $1.59 \pm 0.002$ & $1.61 \pm 0.002$ & 0.18 \\
Added sugar & $22.23 \pm 0.11$ & $22.39 \pm 0.10$ & $22.50 \pm 0.11$ & $22.58 \pm 0.12$ & 0.03 \\
Lactose & $10.43 \pm 0.04$ & $10.50 \pm 0.01$ & $10.58 \pm 0.02$ & $10.64 \pm 0.02$ & \\
\hline
\end{tabular}


Aparna A. Shrivas et al. / J. Appl. \& Nat. Sci. 10 (1): 88 - 97 (2018)

Table 2. Effect of storage period on composition of rava burfi at refrigerated temperature $\left(7 \pm 2^{\circ} \mathrm{C}\right)$.

\begin{tabular}{|c|c|c|c|c|c|c|c|}
\hline \multirow{2}{*}{ Attribute (\%) } & \multicolumn{6}{|c|}{ Mean values of composition on storage for different periods in days } & \multirow{2}{*}{$\begin{array}{l}\text { CD } \\
(\mathbf{0 . 0 5})\end{array}$} \\
\hline & $\mathbf{0}$ & 7 & 14 & 21 & 28 & 35 & \\
\hline Moisture & $19.29 \pm 0.41$ & $18.46 \pm 0.37$ & $17.88 \pm 0.50$ & $17.44 \pm 0.50$ & $16.77 \pm 0.75$ & $16.22 \pm 0.85$ & 1.04 \\
\hline Fat & $18.40 \pm 0.01$ & $18.60 \pm 0.02$ & $18.73 \pm 0.02$ & $18.86 \pm 0.02$ & $19.03 \pm 0.03$ & $19.25 \pm 0.05$ & 0.05 \\
\hline Total protein & $9.47 \pm 0.01$ & $9.58 \pm 0.03$ & $9.66 \pm 0.03$ & $9.75 \pm 0.04$ & $9.80 \pm 0.02$ & $9.89 \pm 0.02$ & 0.05 \\
\hline Ash & $1.57 \pm 0.01$ & $1.59 \pm 0.01$ & $1.60 \pm 0.005$ & $1.61 \pm 0.01$ & $1.62 \pm 0.005$ & $1.63 \pm 0.005$ & 0.012 \\
\hline Added sugar & $22.23 \pm 0.11$ & $22.46 \pm 0.14$ & $22.62 \pm 0.11$ & $22.80 \pm 0.20$ & $23.00 \pm 0.10$ & $23.41 \pm 0.10$ & 0.23 \\
\hline Lactose & $10.43 \pm 0.04$ & $10.54 \pm 0.03$ & $10.63 \pm 0.03$ & $10.70 \pm 0.03$ & $10.79 \pm 0.04$ & $10.89 \pm 0.02$ & 0.05 \\
\hline
\end{tabular}

Table 3. Effect of storage period on physico-chemical properties of ravaburfi at room temperature $\left(30 \pm 2{ }^{\circ} \mathrm{C}\right)$.

\begin{tabular}{|c|c|c|c|c|c|c|c|c|c|}
\hline \multirow{2}{*}{\multicolumn{3}{|c|}{ Attribute }} & \multicolumn{6}{|c|}{$\begin{array}{l}\text { Mean values of physico-chemical properties on storage } \\
\text { for different periods in days }\end{array}$} & \multirow{2}{*}{$\begin{array}{l}\text { CD } \\
(\mathbf{0 . 0 5})\end{array}$} \\
\hline & & & \multicolumn{2}{|c|}{ 0 } & \multicolumn{2}{|c|}{3} & 6 & \multirow{2}{*}{9} & \\
\hline \multicolumn{3}{|l|}{ Acidity (\% LA) } & \multicolumn{2}{|c|}{$0.264 \pm 0.001$} & \multicolumn{2}{|c|}{$0.275 \pm 0.001$} & $0.285 \pm 0.001$ & & 0.002 \\
\hline \multicolumn{3}{|l|}{ Water activity } & \multicolumn{2}{|c|}{$0.813 \pm 0.001$} & \multicolumn{2}{|c|}{$0.796 \pm 0.002$} & 0.750 & & 0. \\
\hline \multicolumn{3}{|l|}{ Free Fatty Acid (FFA) $(\mu$ eq/g) } & \multicolumn{2}{|c|}{$0.63 \pm 0.01$} & \multicolumn{2}{|c|}{$0.69 \pm 0.01$} & $0.72 \pm$ & & 0.015 \\
\hline \multicolumn{3}{|l|}{ Soluble Nitrogen $(\%)$} & \multicolumn{2}{|c|}{$0.11 \pm 0.001$} & \multicolumn{2}{|c|}{$0.13 \pm 0.01$} & & & 5 \\
\hline \multicolumn{3}{|c|}{ 5-Hydroxy Methyl Furfural (HMF) ( $\mu$ moles / 100g) } & \multicolumn{2}{|c|}{$27.29 \pm 0.03$} & \multicolumn{2}{|c|}{$33.79 \pm 0.02$} & & & 05 \\
\hline \multicolumn{3}{|c|}{ TBA (OD) } & \multicolumn{2}{|c|}{$0.083 \pm 0.002$} & \multicolumn{2}{|c|}{$0.090 \pm 0.003$} & $0.10 \pm 0.002$ & $0.17 \pm 0.004$ & 0.004 \\
\hline \multirow{2}{*}{ Attribute } & \multicolumn{8}{|c|}{ Mean values of physico-chemical properties on storage for different periods in days } & \multirow{2}{*}{$\begin{array}{l}\text { CD } \\
(\mathbf{0 . 0 5})\end{array}$} \\
\hline & $\mathbf{0}$ & 7 & & 14 & & 21 & 28 & 35 & \\
\hline Acidity ( & & 0.2 & & $0.276=$ & & 0.002 & 0.28 & & 0.003 \\
\hline Water activity & 0.81 & 0.791 & & $0.783 \pm 0$. & & $0.769 \pm 0.001$ & 0. & & 0.002 \\
\hline Free Fatty Acid (FFA) $(\mu \mathrm{eq} / \mathrm{g})$ & $0.63 \pm$ & 0.634 & & $0.637 \pm$ & & $0.639 \pm 0.001$ & 0.01 & 0.6 & 0.002 \\
\hline \multirow{3}{*}{$\begin{array}{l}\text { Soluble Nitrogen }(\%) \\
5 \text {-Hydroxy Methyl Furfural } \\
(\mathrm{HMF})(\mu \text { moles } / 100 \mathrm{~g}) \\
\text { TBA }\end{array}$} & $0.11 \pm 0.001$ & $0.15 \pm 0$ & & $0.18 \pm 0.00$ & & $0.20 \pm 0.01$ & $0.23 \pm 0.01$ & $0.30 \pm 0.01$ & 0.015 \\
\hline & $27.29 \pm 0.03$ & 30.53 & & $33.60 \pm$ & & $36.20 \pm 0.04$ & $39.60 \pm 0.06$ & $43.14 \pm 0.05$ & 0.07 \\
\hline & $0.083 \pm 0.002$ & $0.089 \pm 0$ & & $0.095 \pm 0.0($ & & $0.10 \pm 0.02$ & $0.15 \pm 0.01$ & $0.23 \pm 0.03$ & 0.025 \\
\hline
\end{tabular}

Table 5. Effect of storage period on rheological properties of rava burfi at room temperature $\left(30 \pm 2^{\circ} \mathrm{C}\right)$.

\begin{tabular}{llllll}
\hline \multirow{2}{*}{ Attributes } & \multicolumn{2}{l}{ Mean values of rheological properties on storage for different periods in days } & CD \\
\cline { 2 - 5 } & $\mathbf{0}$ & $\mathbf{3}$ & $\mathbf{6}$ & $\mathbf{9}$ & $\mathbf{0 . 0 5})$ \\
\hline Hardness (N) & $19.71 \pm 0.10$ & $23.21 \pm 0.10$ & $27.26 \pm 0.10$ & $31.28 \pm 0.10$ & 0.15 \\
Cohesiveness & $0.0027 \pm 0.0001$ & $0.0024 \pm 0.0002$ & $0.0021 \pm 0.0002$ & $0.0018 \pm 0.0002$ & 0.0001 \\
Gumminess (N) & $0.30 \pm 0.01$ & $0.52 \pm 0.01$ & $0.62 \pm 0.01$ & $0.71 \pm 0.01$ & 0.015 \\
Chewiness (N mm) & $2.02 \pm 0.10$ & $2.32 \pm 0.10$ & $2.62 \pm 0.10$ & $2.92 \pm 0.10$ & 0.13 \\
Adhesiveness (N mm) & $1.10 \pm 0.004$ & $1.63 \pm 0.04$ & $2.32 \pm 0.03$ & $2.84 \pm 0.03$ & 0.04 \\
Springiness (mm) & $1.27 \pm 0.01$ & $1.15 \pm 0.01$ & $1.09 \pm 0.01$ & $1.03 \pm 0.01$ & 0.013 \\
\hline
\end{tabular}

the product was unacceptable due to visible mould growth. It can be seen that there was a progressive decrease in the moisture content of the product when stored at refrigerated temperature (Table 2) also. This effect was found to be significant $(\mathrm{P}<0.05)$. After $35^{\text {th }}$ day of storage at refrigeration temperature the product was unacceptable due to textural changes in the product. During storage period, the moisture content of rava burfi decreased rapidly at room temperature as compared to refrigerated temperature. As the storage period progresses, the sample showed an increase in the fat content for both the storage temperatures studied. There was a progressive increase in protein content with increase in storage period at $30 \pm 2{ }^{\circ} \mathrm{C}$, which was found to be significant $(\mathrm{P}<0.05)$. A similar trend was found when the product was stored at $7 \pm 2{ }^{\circ} \mathrm{C}$. A significant $(\mathrm{P}<0.05)$ increase in lactose, sucrose (added sugar) and ash content with increase in storage period for both the temperatures studies was also observed. The decrease in moisture content during refrigerated storage might be due to drying at low temperature $\left(7 \pm 2^{\circ} \mathrm{C}\right)$ and surface evaporation (Sharma et al., 2003). Sachdeva and Rajorhia (1982) and Bhatele (1983) also reported decrease of moisture content during storage of burfiat $30 \pm 2{ }^{\circ} \mathrm{Cand} 7 \pm 2{ }^{\circ} \mathrm{C}$. The increase in protein, fat, lactose, sucrose and ash contents could be attributed to the decrease in moisture content with increase in storage period. Thus, moisture loss during storage with progressive increase in content of other constituents viz. fat, protein, ash, sucrose (added sugar) andlactose either at room temperature or refrigeration temperature is a natural phenomenon as reported by several workers and this is evident in this study also.

Effect of storage on physico-chemical properties of rava burfi: The result of storage period on acidity, water activity, Free Fatty Acid (FFA), soluble nitrogen, 5-Hydroxy Methyl Furfural (HMF) and Thiobarbituric Acid (TBA) content of rava burfi stored at room and refrigerated temperatures are presented in Tables 3 and 4 respectively. 
Aparna A. Shrivas et al. / J. Appl. \& Nat. Sci. 10 (1): 88 - 97 (2018)

Table 6. Effect of storage period on rheological properties of rava burfi at refrigerated temperature $\left(7 \pm 2^{\circ} \mathrm{C}\right)$.

\begin{tabular}{|c|c|c|c|c|c|c|c|}
\hline \multirow{2}{*}{ Attributes } & \multicolumn{6}{|c|}{ Mean values of rheological properties on storage for different periods in days } & \multirow{2}{*}{$\begin{array}{l}\text { CD } \\
(\mathbf{0 . 0 5})\end{array}$} \\
\hline & $\mathbf{0}$ & 7 & 14 & 21 & 28 & 35 & \\
\hline $\mathrm{Hal}$ & 19.71 & $21.82 \pm 0.10$ & $23.84 \pm 0.10$ & $25.65 \pm 0.10$ & $27.55 \pm 0.10$ & $29.67 \pm 0.1$ & 0.18 \\
\hline Cohe & $0.0027 \pm 0.0001$ & $0.0025 \pm 0.0001$ & $0.0022 \pm 0.0001$ & $0.0020 \pm 0.0001$ & $0.0018 \pm 0.0001$ & $0.0014 \pm 0.0001$ & 0.0002 \\
\hline Gumminess $(\mathrm{N})$ & $0.30 \pm 0.01$ & $0.50 \pm 0.02$ & $0.70 \pm 0.02$ & $0.90 \pm 0.02$ & $1.20 \pm 0.02$ & $1.50 \pm 0.02$ & 0.03 \\
\hline Chew & & & & 10 & 0.10 & $2.86 \pm 0.1$ & 0.18 \\
\hline less $(\mathrm{N} \mathrm{mm})$ & $1.10 \pm 0.004$ & $1.56 \pm 0.1$ & $2.23 \pm 0.1$ & $2.71 \pm 0.1$ & $3.25 \pm 0.05$ & $3.76 \pm 0.02$ & 0.13 \\
\hline Springiness (mm) & $1.27 \pm 0.01$ & $1.19 \pm 0.01$ & $1.16 \pm 0.01$ & $1.09 \pm 0.01$ & $1.04 \pm 0.01$ & $0.99 \pm 0.01$ & 0.02 \\
\hline
\end{tabular}

Table 7. Effect of storage period on sensory properties of ravaburfi at room temperature $\left(30 \pm 2^{\circ} \mathrm{C}\right)$.

\begin{tabular}{llllll}
\hline \multirow{2}{*}{ Attributes } & \multicolumn{2}{l}{ Mean values of sensory properties on storage for different periods in days } & CD \\
\cline { 2 - 5 } & $\mathbf{0}$ & $\mathbf{3}$ & $\mathbf{6}$ & $\mathbf{9}$ & $\mathbf{( 0 . 0 5 )}$ \\
\hline Flavour & $8.22 \pm 0.20$ & $8.23 \pm 0.10$ & $7.73 \pm 0.10$ & $6.98 \pm 0.10$ & 0.15 \\
Body and texture & $8.16 \pm 0.15$ & $7.78 \pm 0.10$ & $7.48 \pm 0.10$ & $6.53 \pm 0.10$ & 0.15 \\
Colour and appearance & $8.44 \pm 0.10$ & $8.23 \pm 0.10$ & $7.73 \pm 0.10$ & $6.98 \pm 0.10$ & 0.15 \\
Overall acceptability & $8.48 \pm 0.06$ & $7.83 \pm 0.10$ & $7.48 \pm 0.10$ & $7.02 \pm 0.10$ & 0.15 \\
\hline
\end{tabular}

Table 8. Effect of storage period on sensory properties of ravaburfi at refrigerated temperature $\left(7 \pm 2^{\circ} \mathrm{C}\right)$.

\begin{tabular}{|c|c|c|c|c|c|c|c|}
\hline \multirow{2}{*}{ Attributes } & \multicolumn{6}{|c|}{ Mean values of sensory properties on storage for different periods in days } & \multirow{2}{*}{$\begin{array}{l}\text { CD } \\
(0.05)\end{array}$} \\
\hline & $\mathbf{0}$ & 7 & 14 & 21 & 28 & 35 & \\
\hline Flavour & $8.22 \pm 0.20$ & $7.87 \pm 0.21$ & $7.40 \pm 0.10$ & $6.90 \pm 0.10$ & $6.60 \pm 0.20$ & $6.20 \pm 0.20$ & 0.31 \\
\hline Body and texture & $8.16 \pm 0.15$ & $8.03 \pm 0.06$ & $7.77 \pm 0.25$ & $7.43 \pm 0.21$ & $7.23 \pm 0.25$ & $6.45 \pm 0.02$ & 0.32 \\
\hline Colour and appearance & $8.44 \pm 0.10$ & $8.13 \pm 0.15$ & $8.00 \pm 0.20$ & $7.80 \pm 0.20$ & $7.67 \pm 0.15$ & $6.77 \pm 0.25$ & 0.32 \\
\hline Overall acceptability & $8.48 \pm 0.06$ & $8.13 \pm 0.15$ & $8.00 \pm 0.20$ & $7.80 \pm 0.20$ & $7.67 \pm 0.15$ & $6.20 \pm 0.20$ & 0.30 \\
\hline
\end{tabular}

Table 9. Effect of storage period on microbial quality of ravaburfi at room temperature $\left(30 \pm 2{ }^{\circ} \mathrm{C}\right)$.

\begin{tabular}{llllll}
\hline \multirow{2}{*}{ Attributes } & \multicolumn{2}{c}{ Mean values of microbial counts for different periods in days } & \multicolumn{2}{c}{ CD } \\
\cline { 2 - 5 } & $\mathbf{0}$ & $\mathbf{3}$ & $\mathbf{6}$ & $\mathbf{9}$ & $\mathbf{( 0 . 0 5 )}$ \\
\hline SPC, $\log \mathrm{cfu} / \mathrm{g}$ & $3.78 \pm 0.01$ & $3.81 \pm 0.01$ & $3.83 \pm 0.01$ & $3.88 \pm 0.02$ & 0.017 \\
Yeast and mould counts, cfu/g & $\mathrm{Nil}$ & $\mathrm{Nil}$ & $1.38 \pm 0.02$ & $1.42 \pm 0.03$ & - \\
Coliform counts, cfu/g & $\mathrm{Nil}$ & $\mathrm{Nil}$ & $\mathrm{Nil}$ & $\mathrm{Nil}$ & - \\
\hline
\end{tabular}

Table 10. Effect of storage period on microbial quality of ravaburfi at refrigerated temperature $\left(7 \pm 2^{\circ} \mathrm{C}\right)$.

\begin{tabular}{llllllll}
\hline \multirow{2}{*}{ Attributes } & \multicolumn{9}{c}{ Mean values of microbial counts for different periods in days } & \multicolumn{2}{l}{ CD } \\
\cline { 2 - 7 } & $\mathbf{0}$ & $\mathbf{7}$ & $\mathbf{1 4}$ & $\mathbf{2 1}$ & $\mathbf{2 8}$ & $\mathbf{3 5}$ & $\mathbf{( 0 . 0 5 )}$ \\
\hline SPC, log cfu/g & $3.78 \pm 0.01$ & $3.80 \pm 0.01$ & $4.06 \pm 0.12$ & $4.25 \pm 0.01$ & $4.41 \pm 0.02$ & $4.62 \pm 0.02$ & 0.10 \\
Yeast and mould counts, log cfu/g & Nil & Nil & Nil & $1.95 \pm 0.01$ & $2.20 \pm 0.02$ & $2.48 \pm 0.12$ & - \\
Coliform counts, cfu/g & Nil & Nil & Nil & Nil & Nil & Nil & - \\
\hline
\end{tabular}

It can be seen that the acidity of rava burfi was significantly influenced by storage period when stored at room temperature (Table 3). Similar results were also observed when the product was stored at refrigerated temperatures (Table 4). During storage of rava burfi at refrigerated temperature a significant $(\mathrm{P}<0.05)$ increase in acidity content from $0.264 \pm 0.001 \% \mathrm{LA}$ at $0^{\text {th }}$ day to $0.293 \pm 0.001 \%$ LA at $35^{\text {th }}$ day was observed. It can be seen that the titratable acidity of rava burfi increased at faster rate during storage period at room temperature as compared to refrigerated temperature. The acidity development could be attributed to production of acids like formic acid, acetic acid, lactic acids and other organic acids and FFA as reported by O' Brien (1997). Maillard reaction also produces many organic acids which are also responsible for increase in acidity (Goyal and Shrinivasan, 1988; 1989). Similar findings were reported by Sachdeva and Rajorhia (1982) in burfi during storage. Increase in titratable acidity was also observed during storage of khoa (Kalra et al., 1973). Thus the results obtained in the present investigations corroborates with those reported in literature.
Water activity is defined as the vapor pressure of water in the product divided by that of pure water at the same temperature. Higher $\mathrm{a}_{\mathrm{w}}$ substances tend to support more microorganisms. Bacteria usually require at least 0.91, and fungi at least $0.7 \mathrm{a}_{\mathrm{w}}$ for their growth. Bacterial growth potential can be correlated with moisture in the product concerned. Thus, water activity is helpful in deciding the shelf life of the product either by support or otherwise to the bacterial growth or change in the textural properties due to water transfer. The mean water activity values presented in Table 3 and 4 reveal that water activity of rava burfi was significantly $(\mathrm{P}<0.05)$ reduced during the storage period from $0.813 \pm 0.001$ at $0^{\text {th }}$ day to $0.740 \pm 0.002$ at $9^{\text {th }}$ day of storage at room temperature. As observed from the Table 3 and Table 4, the water activity of rava burfi decreased during storage period at both room temperature as well as refrigerated temperature. This decrease in water activity could be attributed to decrease in moisture of the rava burfi during storage. A similar trend in reduction of water activity of burfi during storage was also reported by Tiwari (2013). Londhe et 
al. (2012) also reported decrease in water activity of brown Peda during storage at $30 \pm 2{ }^{\circ} \mathrm{C}$ using different packaging techniques.

Lipolysis, regardless of cause seriously degrades the quality of the stored product by imparting off flavours and is also responsible for the development of rancidity. In stored dairy products, lipolysis by microbial lipase is of the greatest significance (Murphy and Downey, 1970;Law, 1979). The influence of storage period on FFA content of rava burfi stored at room temperature as shown in Table 3 reveals that the mean FFA value of rava burfi was found significantly affected by the storage period. During storage of rava burfi, a significant increase in FFA content upto $9^{\text {th }}$ day was observed and thereafter the product was found unacceptable due to visible mould growth. This increase in FFA content may be due to the higher SPC and Yeast and mould counts observed at higher temperatures as is evident in Table 9 and Table 10. This increase in FFA content could be attributed to hydrolysis of fat which is primarily affected by the growth of yeasts and molds. In the present investigation also the increase in FFA could be due to increase in yeast and mold count. A similar trend of increase in FFA content during storage was noticed in burfi by Tiwari (2013). Vijaykhder and Patel (1983) also reported an increase in free fatty acids in Peda during storage at ambient temperature $\left(25-29^{\circ} \mathrm{C}\right)$, using polyethylene bags of various densities.

Soluble nitrogen is the measure of water soluble nitrogenous portion of protein. This may result from the degradation of proteins because of proteolysis and hence it serves as an important constituent for monitoring the proteolysis in fermented milk products like chesses. In heat desiccated products such as burfi, it may serve as an indicator of storage related deterioration of milk proteins and some minor solubilization of micellar proteins due to vigorous heat and agitation employed in the process of manufacture of burfi.Tabulated values revealed that the soluble nitrogen of rava burfi samples (Table 3) stored at room temperature was significantly $(\mathrm{P}<0.05)$ affected by storage period. As the storage period advanced, soluble nitrogen increased in rava burfi. It can be seen that soluble nitrogen content of fresh rava burfi was significantly $(\mathrm{P}<0.05)$ increased from $0.11 \pm 0.001 \%$ at $0^{\text {th- }}$ dayto $0.20 \pm 0.01 \%$ at the $9^{\text {th }}$ day of storage at ambient temperature. At refrigerated temperature of storage a similar significant increase in soluble nitrogen was also observed although at lower rate as seen in Table 4. The higher soluble nitrogen content observed could be attributed to the heat treatment employed. The phenomenon of the heat treatment on degradative changes in protein is well established (Jenness and Patton, 1969). On the other hand survival of heat resistant groups of bacteria and heat stable enzymes capable of protein breakdown could be also considered for pro- portionately higher soluble nitrogen content during storage. The increase in soluble nitrogen content on storage might be the direct consequence of degradation of protein content of rava burfi.

The determination of HMF in burfi was done to measure the extent of browning changes during storage. The values presented in the table reveal that the HMF content of rava burfi significantly $(\mathrm{P}<0.05)$ increase with increase in storage period at both the temperatures. At refrigerated temperature $\left(7 \pm 2{ }^{\circ} \mathrm{C}\right)$, the HMF content of rava burfi increased significantly $(\mathrm{P}<0.05)$ from $27.29 \pm 0.02 \mu$ moles / 100 gat $0^{\text {th }}$ dayto $43.14 \pm 0.05 \mu$ moles / 100gat $35^{\text {th }}$ day of storage period. The increased in HMF content in heat treated milk products is an usual phenomenon but could be restricted by controlling factors such as temperature, storage period and certain specific characteristics of the product viz. $\mathrm{pH}$, TS, $a_{w}$ etc. (Walstra and Jenness, 1984). The results obtained in present study are in agreement with the results reported by Patil and Pal (2005) and Sachdeva and Rajorhia (1982) in burfi.

TBA determination is one of several analytical methods for the evaluation of the degree of oxidation of oils and fats. 2-thiobarbituric acid forms red-coloured products with malonaldehyde, some polyunsaturated aldehydes, dioxolanes and furan derivatives. The intensity of colouration is correlated with the rancidity degree of fats and oils.It can be revealed from the Table 3 TBA content of fresh rava burfi was significantly $(\mathrm{P}<0.05)$ increased during storage of rava burfi from $0.083 \pm 0.002$ O.D. (Optical Density) at $532 \mathrm{~nm}$ at $0^{\text {th- }}$ day to $0.17 \pm 0.004$ O.D. at $9^{\text {th }}$ day at $532 \mathrm{~nm}$ at room temperature. At refrigerated temperature the TBA content of rava burfi significantly increased during the storage period at up to $35^{\text {th }}$ day of storage. Thus, it can be concluded that the TBA values of rava burfi during storage period increased more rapidly at room temperature than at refrigeration temperature. The increase in TBA values might be due to oxidation of milk fat and ghee used for roasting of rava of rava burfiduring storage. Increase in TBA values during storage were also noticed by Sachdeva and Rajorhia (1982) in burfi.

Effect of storage on rheological properties of rava burfi: Textural attributes like hardness, cohesiveness, gumminess, chewiness, adhesiveness and springiness, and were analyzed during the storage period. The changes taking place in the textural profile of rava burfi during storage at room and refrigerated temperature are presented in Tables 5 and Table 6 respectively. It can be seen from the Table 5 that the hardness of rava burfi was significantly $(\mathrm{P}<0.05)$ increased during the storage period at room temperature from $19.71 \pm 0.10 \mathrm{~N}$ at $0^{\text {th }}$ day to $31.28 \pm 0.10 \mathrm{~N}$ at $9^{\text {th }}$ day of storage. The effect of storage period at refrigerated temperature $\left(7 \pm 2{ }^{\circ} \mathrm{C}\right)$ on the hardness of rava burfi is depicted in Table 6 . The increase in hardness of samples of rava burfi during storage could be attributed to 
the decrease in moisture content in rava burfi (Table 1 and Table 2). Similar findings were reported by Bhatele (1983) and Tiwari (2013) during storage of burfi. During the storage at room and refrigerated temperatures (Table 5 and Table 6 respectively) the cohesiveness and springiness of rava burfi was significantly $(\mathrm{P}<0.05)$ decreased. The decrease in cohesiveness and springiness might be due to decrease in moisture content on storage resulting into less cohesion of the matrix of the rava burfi. The mean values presented in the Tables 5 and Table 6 show that gumminess, chewiness and adhesiveness values of rava burfi was found to be significantly increased during storage. Tiwari (2013) also reported increase in chewiness during storage of burfi. The increase in chewiness values of rava burfi during storage may be due to increase in hardness values resulting from moisture loss as can be seen from earlier tables for moisture and hardness. Londhe et al. (2012) also reported increase in chewiness value of brown Peda during storage at $30 \pm 2{ }^{\circ} \mathrm{C}$ irrespective of different packaging techniques used. The results obtained in this study are not in agreement with those obtained by Chawla et al. (2013) who reported that textural attributes like adhesiveness, springiness and gumminess of doda burfi, (a similar product which is a burfi prepared from milk solids and germinated wheat flour) showed a significant decreasing trend for storage intervals whereas hardness, chewiness and cohesiveness showed a significant increasing trend in products stored at both ambient $\left(30 \pm 2^{\circ} \mathrm{C}\right)$ refrigerated temperature $\left(7 \pm 2^{\circ} \mathrm{C}\right)$.

Thus, based on the observations from storage products at both the storage temperatures, it can be said that moisture loss during storage mainly affects the textural changes i.e. the inner makeup of the products. These changes have played a major role in deciding the acceptability of stored products, particularly at refrigerated temperature.

Effect of storage on sensory properties of rava burfi: The sensory attributes have profound effect on the consumer's preference. Different food products undergo deterioration in sensory profile as a consequence of various chemical and biochemical changes that progress during storage. The effect of storage period on sensory attributes of rava burfi stored at room temperature is presented in Table 7.

The mean value presented revealed that flavour score of rava burfi was significantly $(\mathrm{P}<0.05)$ reduced during the storage period. During storage of rava burfi, flavour score up to $9^{\text {th }}$ day was observed and thereafter the product became unacceptable due to visible mould growth. From the Table 7 and Table 8 it can be seen that the flavour score decreased rapidly at room temperature as compared to refrigerated temperature during storage. The decrease in flavour score could be attributed to slight loss of freshness, which is inherent with any food product.
In fresh product, the compounds formed during browning reactions are responsible for the typical flavour of the product, but as storage period progresses, the chemical reactions disturbed the delicate balance of the compounds. The findings of the present study are in accordance with the result reported by Biradar et al. (1985) and Londhe et al. (2012) for brown peda andSharma et al. (2003) in Malai Peda samples during storage study. Similar observations were recorded on stored kalakand by Rao and Goyal (2007) and stored doda burfi by Chawla et al. (2013).

It can be seen from Table 7 that body and texture score of rava burfi was significantly $(\mathrm{P}<0.05)$ influenced by the storage period at room temperature $\left(30 \pm 2{ }^{\circ} \mathrm{C}\right)$. During storage of rava burfi the body and texture score decreased significantly from $8.16 \pm 0.15$ at $0^{\text {th }}$ day to $6.53 \pm 0.10$ at the $9^{\text {th }}$ day of storage. Similarly, at the refrigerated temperature, the body and texture score of rava burfi was found significantly $(\mathrm{P}<0.05)$ decreased during storage period Table 8 . The initial mean body and texture score of $8.16 \pm 0.15$ at $0^{\text {th }}$ day decreased to $6.45 \pm 0.02$ at $35^{\text {th }}$ day of storage as per Table 8.The decrease in body and texture score of samples was observed in both the samples kept at different temperatures and it was much faster in the product kept at $30 \pm 2{ }^{\circ} \mathrm{C}$ compared to the samples kept at lower temperatures (i.e. $7 \pm 2{ }^{\circ} \mathrm{C}$ ). A similar decrease in body and texture scores were observed in multigrain halwa samples kept at ambient and refrigerated conditions of storage (Itagi et al., 2011).

Like chemical changes, textural changes also continue during storage in rava burfi. At room temperature the integrity of the grains remained intact, but the grains became harder and chewier becoming conspicuous in the product as the moisture content reduces. At refrigerated temperature the product became dry, hard, sandy and brittle which might be ascribed to the loss of moisture and possible due to crystallization of added sugar. This is because of dynamic structural and conformational changes, which may or may not be dependent on changes in moisture content(Navajeevan and Rao, 2005) and can be attributed to decline in hydrophilic groups. Therefore, body and texture was considered as important criteria for determining the acceptability of rava burfi during storage study particularly at refrigerated temperature $\left(7 \pm 2^{\circ} \mathrm{C}\right)$. The values of these parameters are also supported by the textural parameters such as hardness, cohesiveness and others. The mean values presented reveals that colour and appearance score of rava burfi was significantly $(\mathrm{P}<0.05)$ decreased during the storage period. During storage of rava burfi at room temperature, decreased in colour and appearance score from $8.44 \pm 0.10$ at $0^{\text {th }}$ day to $6.98 \pm 0.10$ at the $9^{\text {th }}$ day of storage was observed. From the Table 7 and Table 8 it can be observed that the changes in colour and appearance scores decreased rapidly at room temperature than at refrigeration tem- 
perature. The decline in scores during storage of rava burfi can be attributed to microbial, chemical and textural changes in the product. During storage the samples became drier in appearance and lacked the greasy appearance desired in good quality burfi which resulted in a steady decrease in colour and appearance scores. The colour and appearance of the product became dull and darker with dry appearance. Moreover in the present study, evaporation of moisture during storage might have aggravated the appearance of the rava burfi as presence of moisture enlivens the appearance of the product by reflecting incident light. Londhe et al., (2012) reported decrease in colour and appearance score during storage study of brown Peda at $30 \pm 2{ }^{\circ} \mathrm{C}$ using different packaging materials. These results are in accordance with those observed by Chawla et al. (2013) who also noted a decrease in colour and appearance scores of doda burfi on storage.

The overall acceptability of stored samples depends upon several factors like degree of proteolysis, extent of lipolysis, flavour changes and microbial activity. Statistical analysis indicated a significant $(\mathrm{P}<0.05)$ difference among the treatment, viz. type of burfi and storage period for both the temperatures studied viz. $30 \pm 2{ }^{\circ} \mathrm{C}$ and $7 \pm 2{ }^{\circ} \mathrm{C}$.As observed from the Table 7 and Table 8 the overall acceptability score decreased rapidly at room temperature compared to refrigeration temperature. The decline in overall acceptability scores of rava burfi was due to changes in flavour and body and texture characteristics. The influence of storage period and temperature of storage was significant for changes in flavour and body and texture and thus, overall acceptability scores. All deteriorative changes, i.e. oxidative, proteolytic, lipolytic, browning, acid development, microbial and textural changes were collectively reflected in sensory quality and thus led to unacceptability of the stored product after a definite period. Low temperature always promotes a longer shelf life of many products and the same was confirmed in this study. This could be attributed to the lower rate of lipid oxidation and non-enzymatic browning reactions which decreases the shelf life of products stored at elevated temperatures (Rossini et al., 2011). Similar effect was found in rava burfi, where the rate of reaction appeared to be very fast at $30 \pm 2{ }^{\circ} \mathrm{C}$ whereas, the same product had a shelf life of 35 day without any sign of spoilage at lower temperature. Hence, the results corroborates with the present finding of this research.

Effect of storage on microbial quality of rava burfi: Most of the milk products are perishable commodities. The perishability of milk products is mostly ruled by microbiological quality of that product. According to BIS (IS:5550:2005) standards laid down for Burfi, the standard plate count should not be more than $30,000 / \mathrm{g}$ and the yeast and mould count not more than $10 / \mathrm{g}$ burfi. The microbial count influences the acceptability and hence, shelf life of any product affecting its colour and appearance, flavour and body and texture of the product. The shelf life of product like rava burfi depends on the growth of microorganisms in the product during storage. Most of the physico-chemical changes as like FFA content, soluble nitrogen, acidity development, change in $\mathrm{pH}$ etc., are affected by the presence and growth of various microorganisms. Increase in FFA and soluble content signifies lipolytic and proteolytic activity caused by microorganisms. Therefore the stored samples of rava burfi were subjected to microbiological analysis for standard plate count (SPC), yeast and mold count (YMC) and coliform count. The influence of period of storage at room temperature $\left(30 \pm 2^{\circ}\right.$ C) on the SPC of rava burfi stored at ambient temperature is presented in Table 9. The mean value presented reveals that SPC of rava burfi was significantly $(\mathrm{P} \leq 0.05)$ influenced by storage period. During storage of rava burfi, significant $(\mathrm{P} \leq 0.05)$ increase in $\mathrm{SPC}$ in both of the packages up to $9^{\text {th }}$ day was observed thereafter the product was found unacceptable due to visible mold growth. The initial mean SPC of $3.78 \pm 0.01 \mathrm{log}-$ $\mathrm{cfu} / \mathrm{g}$ at $0^{\text {th }}$ day increased to $3.88 \pm 0.02 \mathrm{log} \mathrm{cfu} / \mathrm{g}$ at the $9^{\text {th }}$ day of storage. During storage of rava burfi at refrigerated temperature also, a significant $(\mathrm{P} \leq 0.05)$ increase in SPC up to $35^{\text {th }}$ day was observed and thereafter the product was found unacceptable due to visible mold growth. From the table it can be seen that the SPC increases rapidly at room temperature compared to refrigeration temperature during storage period. Sachdeva and Rajorhia (1982) reported increase in SPC during storage of Burfi at $30 \pm 2{ }^{\circ} \mathrm{C}$ and $7 \pm 2{ }^{\circ} \mathrm{C}$. Other workers also reported increasing standard plate counts of Burfi during storage (Garg and Mandokhot, 1984; Misra and Kuila, 1988; Sachdeva and Rajorhia, 1982).

For most of the intermediate moisture Indian dairy foods such as Peda, Burfi, Kalakand, etc. mould growth tends to be a major problem and often most important single factor limiting their shelf life.The influence of period of storage at room temperature $\left(30 \pm 2^{\circ} \mathrm{C}\right)$ on the yeast and mold count of rava burfi is presented in Table 9. The mean values presented reveals that Yeast and mould count of rava burfi was found nil up to $3^{\text {rd }}$ day of storage. During further storage of rava burfi, increase in yeast and mold count up to $9^{\text {th }}$ day was observed and thereafter the product was found unacceptable due to visible mold growth. The influence of period of storage at refrigeration temperature $\left(7 \pm 2^{\circ} \mathrm{C}\right)$ on the yeast and mold count of rava burfi is presented in Table 10. The mean values presented reveals that yeast and mould count of rava burfi was found nil up to $14^{\text {th }}$ day of storage. During further storage of rava burfi, increase in yeast and mold count up to $35^{\text {th }}$ day was observed and thereafter the product was found unacceptable due to visible mold growth. From the Table 9 and Table 10 it can be seen that the yeast 
and mold count increased rapidly with storage period at room temperature compared to refrigerated temperature. The colonies obtained in the present study at room temperature storage were white and green colonies. The numbers of the fungal colonies obtained during present investigation are similar to various workers who had analyzed the milk products like Pedha, Burfi and Kalakand (Biradar et al. 1985, Dwarkanath and Srikanta 1977). Sachdeva and Rajorhia (1982) reported increase in yeast and mold count during storage of Burfi at $30 \pm 2{ }^{\circ} \mathrm{C}$ and $7 \pm 2{ }^{\circ} \mathrm{C}$. The product was found to be free from coliforms and during storage there was no coliform count as presented in Table 9 and Table 10 .

\section{Conclusion}

Based on the results obtained in the present study it can be concluded that the shelf life of rava burfi was found to be 9 days at room temperature $\left(30 \pm 2{ }^{\circ} \mathrm{C}\right)$ and 35 days at refrigerated $\left(7 \pm 2^{\circ} \mathrm{C}\right)$ temperature when packed in composite polyethylene terephthalate (PET)/ low density polyethylene (LDPE) film. During storage period there was a decrease in moisture content and water activity and an increase in fat, protein, lactose, ash, added sugar, acidity, FFA, soluble nitrogen, TBA and HMF both at ambient $\left(30 \pm 2{ }^{\circ} \mathrm{C}\right)$ as well as at refrigerated $\left(7 \pm 2^{\circ} \mathrm{C}\right)$ temperature.

\section{REFERENCES}

Aneja, R.P., Mathur, B.N., Chandan, R.C. and Banerjee, A.K. (2002). Technology of Indian milk products, Dairy India Yearbook, A Dairy India Publication, New Delhi, pp: 74- 96, 99-101.

Anon (1979). Annual Report CFTRI, Mysore. 1978-79:31.

Anon (2012). Department of animal husbandary. Dairying and Fisheries, Ministry of Agriculture. Cited from www.nddb.org.

AOAC (1970). Official methods of analysis of the association of official analytical chemists methods of analysis.

Bhatele, I.D. (1983). Studies on the production, packaging and preservation of burfi, Ph. D. Thesis, Kurukshetra University, Kurukshetra.

Biradar, U.S., Dev, D.K. and Ingle, U.M. (1985). Shelf life extension of pedha by packaging. J. Food Sci., 50(1): 51-55.

Chawla, R., Patil, G.R. and Singh, A.K. (2013). Effect of temperature on sensory and textural attributes of functional doda burfi (Indian milk cake). J. Food Sci. Technol., DOI 10.1007/s13197-013-1027-6.

Deeth, H.C., Fitz-Gerald, C.H. and Wood, A.F. (1975). A convenient method for determining the extent of lipolysis in milk. Aust. J. Dairy Technol., 30(3): 109-111.

Dwarkanath, C.T. and Srikanta, S. (1977). Studies on the microbiological quality of traditional Indian sweet meat products. J. Food Sci. Technol., 14: 201-204.

Garg, S.R. and Mandokhot, U.V. (1984). Studies on microbial and chemical profile of some Indian sweetmeats and their significance. Indian J. Dairy Sci., 37(4): 326-333.

Goyal, G.K., Srinivasan, M.R. (1988). Protective role of packaging materials in refrigerated conditions on the microbiological quality of khoa. Asian J. Dairy Res., 7: 66-72.

Goyal, G.K., Srinivasan, M.R. (1989). Effect of packaging on the chemical quality of khoa during storage. Indian J. Dairy Sci., 42: 165-170.

IS:1155 (1968). Specifications for Wheat Atta. In: ISI Handbook of Food Analysis. Part IV (1984). p 115.

IS:1166 (1968). Specifications for condensed milk, partly skimmed and skimmed condensed milk (second revision), Indian Standards Institution, Manak Bhavan, New Delhi.

IS:1479 (Part II) (1961). Methods of test for dairy industry, (Part II). Chemical analysis of milk, Indian Standards Institution, Manak Bhavan, New Delhi.

IS:1547 (1985). Specifications for Infant Milk Foods. Bureau of Indian Standards, Manak Bhavan, New Delhi.

IS:2311 (1963). Fat extraction apparatus for milk and milk products (first revision), Indian Standards Institution, Manak Bhavan, New Delhi.

IS:2802 (1964). Specifications for ice-cream. Indian Standards Institution, Manak Bhavan, New Delhi.

IS:5550 (2005). Indian Standard specification for Burfi, Indian Standards Institution, New Delhi.

IS: 1010 (1968). $1^{\text {st }}$ Revision. Indian Standards specifications for suji or rawa (Semolina). Bureau of Indian Standards, New Delhi.

ISI Handbook of food analysis (1989). SP: 18 (Part XI Dairy Products). Bureau of Indian Standards, Manak Bhavan, Bahadur Shah Zafar Marg, New Delhi, India.

Itagi, H.N., Singh, V., Indiramma, A.R. and Prakash, M. (2011). Shelf stable multigrain halwa mixes: preparation of halwa, their textural and sensory effect. J. Food Sci. Technol. DOI: 10.1007/s13197-011-0423-z.

Jenness, R. and Patton, S. (1969). Milk Proteins. In: Principles of Dairy Chemistry. John Wiley and Sons Inc. pp 101-157.

Kalra, M.S., Laxminarayan, H. and Dudani, D. (1973). Use of nisin for extending shelf-life of processed cheese and khoa. J. Food Sci. Technol., 10: 92-94.

Keeney, M. and Bassette, R. (1959). Detection of Intermediate Compounds in early stages of reaction in milk products. J. Dairy Sci., 42(6): 945-960.

Khan, M.A., Semwal, A.D., Sharma, G.K., Yadav, D.K. and Srihari, K.A. (2008). Studies on the development and storage stability of Groundnut (Arachis Hypogea) Burfi. J. Food Quality, 31: 612-626.

Kosikowaski, F. (1982). Cheese and Fermented milk Products. Kosikowaski F.V. (Ed), Associates Publ. New York, p 568.

Law B.A. (1979). Enzymes of psychrotrophic bacteria and their effect on milk and milk products. J. Dairy Res., 46: 573-588.

Londhe, G., Pal, D. and Raju, P.N. (2012). Effect of packaging techniques on shelf life of brown peda, A milk based confection. Food Sci. Technol., 47: 117-125.

Millward, D.J., Fereday, A., Gibson, N.R., Cox, M.C. and Pacy, P.J. (2002). Efficiency of utilization of wheat and milk protein in healthy adults and apparent lysine requirements determined by a single-meal $\left[1-{ }^{13} \mathrm{C}\right]$ leucine balance protocol. Am. J. Clin. Nutr.,76:1326-34.

Misra, A.K. and Kuila, R.K. (1988). Microbiological quality of burfi and sandesh. Asian J. Dairy Res., 7(1): 51-55. 
Murphy, R.F. and Downey, W.K. (1970). Characterization of the esterase activity of bovine mammary gland secretion. XVIII Int. Dairy Cong. 1. E, p. 604.

Navajeevan, B. and Rao, K.J. (2005). Physico-chemical changes in retort processed kunda. Indian J. Dairy Sci., 58(6): 392-398.

O' Brien, J. (1997). Reaction chemistry of lactose: nonenzymatic degradation pathways and their significance in dairy products. In: Fox PF (Ed) Advanced Dairy Chemistry, Vol. 3. Chapman \& Hall, Madras, p 248.

Patil, C. and Pal, D. (2005). Studies on mechanized production and shelf life extension of Burfi. Indian J. Dairy Sci., 58(1): 12-16.

Rao, R.S. and Goyal, G.K. (2007). Effect of packaging and storage on the sensory quality of Kalakand. Indian $J$ Dairy Sci., 60(2): 77-80.

Rossini, K., Caciano, P.Z., Brandelli, (2011). Changes in the colour of white cholcolate during storage: Potential roles of lipid oxidation and non-enzymatic browning reactions. J. Food Sci Technol., 48(3): 305-311.

Sachdeva, S. and Rajorhia, G.S. (1982). Studies on the technology and shelf life of Burfi. Indian J. Dairy Sci., 35: 513-516.

Sarkar, K., Ray, P.R. and Ghatak, P.K. (2002). Effect of sodium and potassium metabisulphites on the shelf-life of cow milk burfi. Indian J. Dairy Sci., 55: 79-82.
Sharma, H.K., Singhal, R.S. and Kulkarni, P.R. (2003). Effect of modified atmosphere packaging on the keeping quality of malai peda. J. Food Sci. Technol., 23(5): 543545 .

Shrivas, A.A., Pinto S.V. and Patel, S. (2015). Manufacture of Rava Burfi. Asian Academic Research Journal of Multidisciplinary., 2(2): 432-443.

Steel, R.G.D. and Torrie, J.H. (1980). Principles and procedures of statistics - A biometrical approach, $2^{\text {nd }}$ Edn, New York: McGraw Hill, pp 137-167.

Stone, H. and Sidel, J.L. (2004). In: Sensory evaluation practices, 3rd Edn. Elsevier Acad. Press, NY, p 88

Strange, E.D., Benedict, J.L. Smith and Swift, C.E. (1977). Evaluation of rapid tests for monitoring alterations in meat quality during storage. J. Food Prot., 10: 843-847.

Tiwari A. (2013). Assessing the suitability of sweet cream buttermilk in preparation of burfi. M.Tech Thesis. Anad Agricultural University, Anand, Gujarat, India.

Vijayalakshmi, N.S., Indiramma, A.R., Viswanath, P., Dattatrey, A. and Kumar, K.R. (2005). Extension of the shelf-life of Burfi by packaging. J. Food Quality, 28(2): 121-136.

Vijaykhder, and Patel, Y.K. (1983). Composition and packaging of Peda. Indian J. Dairy Sci.,36:187.

Walstra, P and Jenesse, R (1984). Properties of milk concentrates. In: Dairy Chemistry and Physics, John Wiley \& Sons, New York, pp 301-315. 